\title{
Global Mobility and the Media
}

\author{
Presenting Asylum Seekers as a Threat
}

\author{
KARINA Horsti
}

Just after the summer holiday season had started in late June 1999, the Finnish media began reporting the numbers of Slovakian Roma asylum seekers. The public heard about Roma who were 'flooding', 'flowing', and 'mass immigrating' Finland. The Finnish government stopped the process two weeks after the media began to report by imposing a temporary visa requirement for Slovakian citizens. All together Finland received a thousand asylum seekers from Slovakia during a three week period in summer 1999. By Finnish standards this was an exceptionally high number. The media framed the Roma as 'economic refugees'. Instead of expressing this accusation explicitly the media constructed an image of a shady group of people with illegitimate reasons from more subtle details. This article identifies five key themes that were chosen to frame the story: the flood theme, the illegitimacy theme, the fortress theme, the reputation theme, and the lax policy theme. Choosing these themes the media constructed an image of asylum seekers which enter the country without true reasons, therefore they present a threat to the society as well as to its asylum and human rights policies.

'Economic refugees' is a catch phrase that has been repeated in the everyday language of the Finns since the early 1990's. The Finns who have left the country for a better future to neighbouring Sweden or to more distant places have been regarded as adventurous, active, and having courage. The label 'economic refugees', however, has a negative connotation and it is being used to characterize some immigrants and refugees coming to Finland. It refers to laziness and illegitimate reasons. It is used especially in everyday language, not so much in ad-

Department of Journalism and Mass Communication, University of Tampere, FIN-33014 Tampere, karina.horsti@uta.fi ministrative discourse. This article investigates how the media deal with the issue. It suggests that the media play a central role in the making of "economic refugees'.

Textual and visual details are analyzed with discourse and frame analysis. Moreover, journalistic genres and professional practices are studied. The case is also investigated from the perspective of globalization theory. The practical research question is: How do the media represent asylum seeking and the Roma? Is there any variation between media and genre? But the broader question is: How does the representation relate to globalization? Mobility is one characteristic of globalization. However, only some people are welcome to move around, while others are being pushed away. The media are significantly involved with the process of constructing and defining distances, borders, and otherness.

\section{Mobility: Diasporas of Fantasy and Diasporas of Despair}

The popular diagnosis of our time (since the 1980's) emphasizes globalization. It suggests that the world we live in is no longer divided much by state borders. Money, goods, images, and people move across nation-state borders which used to characterize the modern world. And they move at an increasing speed. The divisions are still there, however. Not everyone or everyone's goods, images or money are able to move in an equal way. As Zygmunt Bauman $(1998,2)$ formulates it, the uses of time and space are sharply differentiated as well as differentiating. Globalization divides as much as it unites.

Globalization theory also refers to compression of time and space. Though distances have shrunk and lost meaning for some people, they can move easily and freely in global and local settings, time is 
something they do not have enough of. Timetables, calendars, mobile phones, and quick lunches are signifiers of a successful life. On the other hand, people who are stuck in their localities, who do not have the opportunity to move in space, have plenty of time. (Bauman 1998, 2, 8-10.)

The degree of mobility, a person's freedom to choose where to be, is one segregative factor in global and local settings. Everything and everyone is on the move. Even though someone might not want to be moving or imagining moving, the surrounding locality certainly is changing rapidly. Job opportunities and situations are changing due to whatever is best for the international finance market, cost of living and housing are changing, even the climate, and states have less control over these matters. Those who can afford it, abandon the filth of the regions that those who cannot afford to move are stuck in.

Arjun Appadurai (1996, 33-37) distinguishes continuous global cultural flow, the movement and change, into five dimensions: ethnoscape, mediascape, technoscape, finanscape, and ideoscape. According to Appadurai these landscapes are the building blocks of 'imagined worlds'. By saying that he extends the idea of 'imagined communities' (Anderson, 1983), the idea of nations and nationalities being constructions of shared images of common past and character. Where Anderson emphasizes the role of printed media in the making of these imagined communities, Appadurai points towards the electronic media with the idea of mediascape. He argues that the electronic media, television and internet especially, are producing and distributing images of attractive lives. These images help to constitute fantasies of possible lives elsewhere. Therefore, Appadurai argues, the media are partly increasing migration and deterritorialization, that is changes on the level of ethnoscape.

In this article it is more important to ask how mobility divides than what kind of mobility takes place. Both Appadurai and Bauman stress that there is a difference between various groups moving and between various groups staying in their localities. Bauman $(1998,92)$ talks about tourists and vagabonds. Tourists are on the move because they want to, vagabonds because they have to. Tourists move either because they consider it the most reasonable life-strategy or because they have been seduced by the imaginary pleasures of life elsewhere. Vagabonds, on the other hand, are on the move because staying in their localities would be a humiliation. Their diaspora is anything but the manifestation of freedom.
Appadurai $(1996,6)$ has a similar idea, but following Albert Hirschman's (1970) terms loyalty and exit, he talks about diasporas of hope, diasporas of terror, and diasporas of despair. There are people who imagine routinely the possibility that they or their children could live and work in places other than where they were born. And, there are people who are forced into new settings, such as refugee camps.

Compression of time and space for an increased number of people, especially for many Westerners, has resulted in increasing contacts among the upper part of global hierarchy than between the bottom and top inside one region or nation-state (Bauman $1998,88)$. From the media studies point of view it is important to ask what kind of communication goes on in the media. Whose views are presented, whose views are not? Are the media communicating only among those who enjoy compression of space?

\section{The Gates of a Nation State: Finland's Immigration Control}

The diminished power of nation states is one of the central issues in globalization theories. European states, for instance, have given some of their powers to EU institutions. However, the symbols of a nation-state are still at the border control: passports, immigration officials, and security checks. The nation-state guards who is being let in and who is being left out. Though for some people border controls are almost invisible, for others they are tight. Visas and passport controls are important symbols of global hierarchy. There is going to be a shift in these symbols after the Schengen agreement is adopted. The emphasis of control will shift from nation-state border to EU border. Finland as a member of the agreement will have an important role as the gate-keeper at the eastern border next to Russia. There is a tendency to construct a fortress with immigration control around Europe rather than around separate member states. All EU countries have tightened their immigration control during the last few years.

Finland has a comparatively small amount of asylum seekers and refugees. For instance, Finland received only approximately one hundred asylum applications per month during the first half of 1999 . By comparison Sweden received more than 800 and Norway 500-800 applications per month. These numbers are small compared to southern or central EU countries.

The border of stricter restriction, a visa, runs near the Eastern end of the European Union. There 
are some countries in between, like the Baltic countries, Poland, Slovakia, and the Czech Republic whose nationals do not need a visa, but have more difficulties in settling in the country than EU nationals. The Finnish government imposed a temporary visa requirement for Slovakians twice after the Roma came to Finland seeking asylum.

The Roma case, and especially its presentation in the media, is important in the making of Finnish immigration policy. Media's role in politics in general has increased as political life tends to be constituted through media. However, this is only one side of the new shifts in the Finnish politics. EU decision making is highly criticised of its democracy deficit and its tendency to keep decision making out of the public sphere. Finnish national politics have been more open to public sphere than the EU politics. In the late 1990's top decision makers in Finland, however, tend to regard public sphere as dangerous and directed mainly to assure markets rather than as a sphere for public discussion (Kantola 2001). Therefore, there is a contradiction in changes. The media is increasingly important in politics, but decisions and negotiations are rather done in privacy. It is necessary to study which political arguments and actors are willing to step in to the public arena in the context of asylum seeking and which arguments and actors keep themselves in silence.

\section{The Marginalized Roma}

Emigration and mobility have been features of the Roma's history. They have moved across Europe mainly because of hostility from majority groups. The first Roma arrived to Finland in mid 1500's while Finland was part of Sweden. Today there are 6000-7000 Roma in Finland as well as approximately 3000 Finnish Roma living in Sweden. The Roma have been the main "Other" in the Finnish society before the 1990's when the number of immigrants began to rise. During the last 450 years the majority has had hostile or patronizing attitudes towards the Roma. Assimilation has been the authorities' goal at least from the 1800's when the construction of the national spirit began. The strength of the nation was seen in homogeneity, therefore, ethnic difference was regarded as a threat to the national unity. The Roma began to organize pressure groups from the 1960's onwards and the policy has changed to more equal direction in the 1990's. The majority of the Roma are living with the help of welfare and many of the problems connected with them are the same with any social group or family living in a marginal position: poor housing, educa- tion, crime, and poverty. Subject positions which seem to be accepted outside this category of 'social problem" are those of a musician or a race horse owner. (Grönfors 1997, 149-160.)

The Roma in Eastern Europe face much harder conditions than the Finnish Roma. Marginalization in Finland can be characterized as implicit and structural, where as the Roma in Eastern Europe face additionally more open racism and physical violence. European Roma Rights Center for instance reports continuous skinhead violence and police's disparagement of this violence in Slovakia since the country took independence in 1993. The Roma began to flea attacks and poor social conditions from many Eastern European countries after the fall of communism. Many of them have been moving to and between Western European countries during the 1990's. (Cahn and Trehan 1997.) The first Eastern European Roma reached Finland in 1999, from Slovakia. This article analyses the first two weeks of the coverage of the Roma from Slovakia. The strongest manifestation of hostility towards the Roma in Europe has been the holocaust. For instance the whole Roma population of Estonia, the Netherlands, Lithuania, and Luxemburg was destroyed by the Nazis in concentration camps (Grönfors 1997, 152-153). Europeans have mainly forgotten this part of history. The history of the holocaust and the treatment of the history today present the two discriminating practices used against the Roma throughout the history: hostility and negligence.

Another minority group that appears important in this article is the Swedish speaking Finns. The Swedish speaking minority are usually characterized as a cultural or linguistic minority rather than an ethnic minority.

Comparisons between the Swedish language and Finnish language media are rare in the context of reporting of ethnic minorities. However, this analysis highlights an interesting division between the two media. The Swedish language media tends to adopt a slightly more critical stand towards the Finnish government and officials. However, it should be noted that minority rights have been an important political issue among the Swedish speaking minority.

Approximately 300000 Finns speak Swedish as their mother tongue, less than 6 per cent of the population. Swedish language was the language of the upper-class from the middle ages until the late 1800 's when a construction of national spirit raised the status of Finnish. Historical background of the Swedish speaking group is diverse: merchants, officials, and noblemen who moved from Sweden to Finland, Finnish speaking peasants who raised to 
the upper class and adopted Swedish language, and Swedish speaking peasants. Swedish speaking peasants and upper class were not socially connected before the late 1800's when the nation building project began. Later on the Swedish speaking minority has acted politically more unanimously for their minority rights. In the present Finland they have a relatively good position in economical, social, and political terms. Swedish speakers' socio-economic status is a bit higher than the Finnish speakers'. Swedish is an official language in Finland along with Finnish. (Finnäs 1997, 63, 69-71; Liebkind 1997, 68-69.)

\section{Analyzing Frames, Journalistic Practice, and Socio-Cultural Context}

The media coverage of the Slovakian Roma is approached with discourse analytical perspective, that is, language is regarded as a socially constitutive element. Language use constructs, changes and reproduces social reality. Therefore, it has consequences. Critical discourse analysis, in particular, studies the relations between language and power. Though possibly important to the workings of power, connections between language use and the exercise of power are often not clear to people. (Fairclough 1995, 54-55.)

The material is studied in the spirit of Fairclough's critical discourse analysis both on the textual and contextual level. Firstly, representations are analyzed on the textual level. Secondly, the role of journalistic routines and genres is discussed. Finally, the results are discussed in a social and cultural framework. How is the case related to the Finnish immigration politics and to globalization? (Fairclough 1995, 59).

The idea of framing is used alongside the discourse analytical approach. The scholarly view of framing is based on the work of sociologist Erving Goffman (1974). His work, however, is based on an individual's cognitive framing process, whereas the recent studies (Entman 1991, Gamson \& Modigliani 1989, Wall 1997) in the field of communication highlight the socio-cultural context of the framing process along with the individual level. According to Goffman $(1974,10-11)$ framing is a strategy to make sense of events and things. This is the core of framing. In recent times, the analysis of how news stories are framed and what effects the frames have has been a growing area in the study of journalism (see for instance Entman 1993).

Journalism, especially the news genre, tends to present themes in simplifying frames, so that topics will be easier to deal with. The main duty of a jour- nalist is to simplify complicated issues and try to frame them attractively. Another typical feature of journalistic practise is continuity. Spin-off reports of a case should fit the frame defined in the earlier stories. Moreover, one news event may turn into a key event, when similar events get more attention (Brosius and Eps 1995). The media are likely to frame subsequent events from the viewpoint of the key event. However, frames may change during the process of reporting, and there might be more than one frame in a single story. (Entman 1993, 52.)

In the case of the Roma, the main frame in the media as well as among its main authoritative sources, is the frame of threat. The underlying ideology is that the Roma are not in real need of asylum, but that they are trying to threaten Finland's order, trying to cause chaos by misusing asylum policy. This frame is not expressed explicitly, on the contrary it is constructed of various implicit frames, which I call here themes. The flood theme illustrates a scene where there is an uncontrolled and continuous 'flood' of immigrants pouring into Finland. The fortress theme presents a solution to the flood problem: visa regulations and a need to tighten the Aliens Act are suggested. These demands are sometimes disturbed by themes related to Finland's reputation. Though this is not a major problem, the media at times wonder if tightening immigration control would give the country a bad name. Themes referring to illegitimacy or having no justification for an asylum back up fortress and reputation themes.

\section{Two Week Negotiation in the Media}

The case of the Roma can be defined as a key event (Brosius and Eps 1995). It was the first time that Eastern European people seeking asylum hit the news agenda in the country. Moreover, during the two week coverage (28.6.-11.7.1999) Finnish immigration policy was questioned in public. The media continue referring to the case when it covers issues of the new Aliens Act. On the other hand, there have been previous events which clearly have set the frame for this event. Coverage of previous asylum seekers, like the Somalis in the early 90's was framed according to the flood frame (Blomqvist 1996). Previous studies have repeatedly characterized the Finnish media's portrayal of ethnic minorities as exclusive in subtle ways. The media have been criticized of leaving ethnic minorities silent as sources and of concentrating on negative representations such as problems and crime. This tendency has not changed considerably during the last ten years. (Pietikäinen 2000, Raittila 2002.) 
The frame of threat in the context of Roma asylum seekers is not unexpected, but the aim of this study is to present in more detail how the frame is constructed. Moreover, variation between media and genres is studied. It is also necessary to analyze the event as a whole: how did the media and various genres react to the event in various phases? Additionally, the frame of threat is examined in the current social, cultural, and political context. The aim is to discuss how the media is involved with policy making and (re)constructing global hierarchies.

The research material includes news and feature stories published during two weeks in the largest and the only nation wide Finnish language daily newspaper Helsingin Sanomat (32 stories), Swedish and Finnish language television programmes from two channels owned by the National Broadcasting Company YLE (32 stories), a regional paper Kymen Sanomat (23 stories), and the main Swedish language newspaper Hufvudstadsbladet (17 stories). The total amount of stories is $104^{1}$.

The two week period can be divided into four phases. The first one begins on the $28^{\text {th }}$ of June apparently with an anonymous phone call to major newsrooms. The caller states that some 300 asylum seekers have arrived from Slovakia. The national media report numbers, details on relocation, and the amazement of the Finnish authorities. Flood theme dominates.

The Prime Minister, Paavo Lipponen, states in an EU meeting that Slovakia should improve the Roma's conditions. This statement, however, does not gain extensive publicity. It is disregarded by some media, for instance the main newspaper, Helsingin Sanomat. However, the Swedish language media refers to the statement frequently afterwards.

The Minister of the Interior, Kari Häkämies, takes an active role right at the beginning by stepping forward with his press release on the $30^{\text {th }}$ of June. He suggests that Slovakians' applications should be dealt with in an urgent procedure, because according to him it is obvious that these applications are without justification. Moreover, he suggests, that the Finnish Aliens Act should be changed so that asylum seekers without justification could be turned back speedily. This press release sets the agenda: tightening the Finnish Aliens Act becomes an issue which is negotiated in the media. In the second phase, 2.7.- 4.7., the national Finnish language media, namely the $H S$ and $Y L E$, discuss fortress themes eagerly. The Minister stays in the media: he willingly makes statements to the media.

Furthermore, feature stories and commentaries are published alongside with news stories from the second phase onwards. ${ }^{2}$ After the first days of amazement the media concentrate on the issue of the Roma in greater detail. The print media publish background stories and letters to the editor as well as editorials. Television brings up the issue of asylum seekers into their current affairs programmes and discussion programmes. Though features and commentaries do bring more sources and viewpoints into the public sphere, it should be noted that the primary-news dominated treatment has already set the agenda for discussion. Themes and viewpoints are presented in the first-order news presentation. The media treatment of the Roma begins with questions: Who are these people? Are they true asylum seekers or are they making a fraud? Therefore, the subsequent feature stories and commentaries present 'answers'. News stories tend to provide the foundation for most editorials and letters to the editor. (See Hall et al. 1978, 88-89.)

For instance an insert to an interview with a Finnish professor of cultural anthropology frames the interview as an answer to questions set by previous news coverage:

\section{When the Albans fleeing Kosovo arrived to Finland people collected tons of food and clothes for them. When the Roma fleeing Slovakia came here the headlines ask: 'Etno- tourism or real despair?'. (Morning discussion programme, YLE 1. 2.7.1999.)}

The excitement as to what will happen with the Roma issue continues until a temporary visa requirement of four months is announced on the 6th of July. An interesting turn takes place when the Finnish and Slovakian Secretaries of State meet and give a press conference. The coverage shows how the media prefer authoritative sources. Critical views towards the Slovakian Secretary of State are rare. On the contrary, doubts about the Roma being economic refugees and not really facing serious discrimination are reinforced.

After the visa requirement only a few Roma arrive. The story dies down. The asylum seekers are accommodated in reception centres where they wait until their applications are processed. The issue of changing the Finnish Aliens' Act returns to the public sphere in 2000 .

These four phases actually represent the situation in the national media ( $H S, Y L E$, and $H B L)$. The regional daily newspaper, Kymen Sanomat, reacted only after the theme had become a main national news topic. It made the case regionally appealing by interviewing a Roma family from Slovakia who had been located in town. Moreover, Kymen Sanomat 
Table 1. Four Phases of the Coverage

\begin{tabular}{|c|c|c|c|c|c|c|c|c|c|c|c|c|c|}
\hline \multicolumn{4}{|c|}{$\begin{array}{l}\text { 1. phase: amazement, numbers, mostly } \\
\text { flood theme, news genre dominates }\end{array}$} & \multicolumn{3}{|c|}{$\begin{array}{l}\text { 2. ph: feature stories and com- } \\
\text { mentaries, fortress theme } \\
\text { suggested }\end{array}$} & \multicolumn{4}{|c|}{$\begin{array}{l}\text { 3.phase: feature stories and commentaries, fortress } \\
\text { theme, frame 'economic refugees' completed }\end{array}$} & \multicolumn{3}{|c|}{ 4. phase: story dies down } \\
\hline Mon & Tue & Wed & Thu & Fri & Sat & Sun & Mon & Tue & Wed & Thu & Fri & Sat & Sun \\
\hline 28.6 & 29.6 & 30.6 & 1.7 & 2.7 & 3.7 & 4.7 & 5.7 & 6.7 & 7.7. & 8.7 & 9.7 & 10.7 & 11.7 \\
\hline $\begin{array}{l}\text { An anonymous } \\
\text { phone call }\end{array}$ & & $\begin{array}{l}\text { Minister of } \\
\text { Interior's } \\
\text { press release }\end{array}$ & $\begin{array}{l}\text { Prime Minister's } \\
\text { statement in } \\
\text { an EU meeting }\end{array}$ & & & $\begin{array}{l}\text { Announced: } \\
\text { two new } \\
\text { reception centres } \\
\text { will be opened }\end{array}$ & $\begin{array}{l}\text { Secretaries } \\
\text { of State meet } \\
\text { s }\end{array}$ & $\begin{array}{l}\text { Announced: } \\
\text { temporary visa } \\
\text { requirement }\end{array}$ & $\begin{array}{l}\text { Visa is } \\
\text { required of } \\
\text { Slovakian } \\
\text { citizens }\end{array}$ & & & & \\
\hline HS stories 0 & 1 & 3 & 1 & 2 & 2 & 3 & 2 & 2 & 6 & 7 & 2 & 1 & 0 \\
\hline KS stories 0 & 0 & 0 & 2 & 3 & 0 & 0 & 2 & 4 & 3 & 2 & 2 & 5 & 0 \\
\hline Nytt stories 0 & 1 & 1 & 0 & 1 & 1 & 2 & 3 & 1 & 1 & 0 & 0 & 0 & 0 \\
\hline $\mathrm{HBL}$ stories 0 & 1 & 0 & 2 & 2 & 2 & 1 & 1 & 1 & 3 & 1 & 1 & 1 & 1 \\
\hline $\begin{array}{ll}\text { YLE news } & \\
\text { stories } & 1\end{array}$ & 1 & 1 & 0 & 1 & 1 & 1 & 2 & 2 & 1 & 1 & 1 & 0 & 0 \\
\hline $\begin{array}{l}\text { YLE feature/ } \\
\text { disc. Finnish }\end{array}$ & 1 & 0 & 0 & 1 & 0 & 0 & 0 & 3 & 2 & 0 & 0 & 0 & 0 \\
\hline $\begin{array}{l}\text { YLE feature } \\
\text { Swedish }\end{array}$ & 0 & 0 & 0 & 0 & 0 & 0 & 0 & 1 & 0 & 0 & 0 & 0 & 0 \\
\hline Total & 5 & 5 & 5 & 10 & 6 & 7 & 10 & 14 & 16 & 11 & 6 & 7 & 1 \\
\hline
\end{tabular}

$H S=$ Helsingin Sanomat, the largest quality daily newspaper in Finland.

$K S=$ Kymen Sanomat, a regional daily paper.

$N y t t=$ National Broadcasting Company YLE, Swedish language television news at 18.15 .

$H B L=$ Hufvudstadsbladet, Swedish language daily paper.

YLE news= National Broadcasting Company YLE, Finnish language television news daily at 20.30.

$Y L E$ feature/discussion= Feature programmes and morning discussions. 
continued with the issue longer than the national media. On the 5th of July it reported that a new refugee centre was to be opened in the region. This generated a continuous flow of news, reportage, letters to the editor, and columns.

\section{Themes which Construct a 'Threat'}

The media presented the Roma case with a main frame of 'threat'. Though the asylum seekers were families, most of them children, the media presented them as a threat to the Finnish society and its law and order. This main frame is constructed with five key themes, discourses which overlap institutions. These are the flood theme, the fortress theme, the illegitimacy theme, the reputation theme, and the lax policy theme. These themes support each other and construct the basis for the definition of a threat. There are alternative themes, like the Roma's experience of violence, but the following dominate.

The flood theme is the strongest one throughout the coverage. Typical catchphrases are 'flood of immigrants, stream, flow, mass immigration, and invasion'. Using such metaphors assumes that asylum seeking is uncontrollable and continuous. Administrative problems, such as lack of interpreters and rooms are a big issue. The flood theme gets stronger when future chaos is being speculated.

Visual images support textual dimensions. Television especially produces images, visual metaphors, of 'flood'. It needs visual images for its news stories (which are often follow up stories telling new numbers) more than the printed media. The audience sees frequently how the Roma 'flow' in a continuous stream towards the camera from customs at the airport or how large coach busses are fully seated by the Roma. Moreover, in newspapers instead of showing individuals most visual images present groups of more than three.

The reporting begins with questions: What is causing the 'flood'? Why are they coming to Finland? In the following news coverage as well as in other genres of commentary and feature there is a tendency to frame the causes firstly as the Roma's fault and secondly as the fault of the 'attractive' asylum policy of Finland. The Roma are presented as being economic refugees, leaving their 'home' for the attractive social benefits of a welfare state. The

Table 2. The Main Frame of 'Threat'

\begin{tabular}{|c|c|c|c|c|c|}
\hline & Flood theme & Fortress theme & Illegitimacy theme & Reputation theme & Lax policy theme \\
\hline Characteristics & $\begin{array}{l}\text { Asylum seeking } \\
\text { seems } \\
\text { uncontrolled and } \\
\text { continuous. } \\
\text { Speculation on } \\
\text { future chaos. } \\
\text { Emphasis on } \\
\text { administrative } \\
\text { problems. }\end{array}$ & $\begin{array}{l}\text { Discussing if visas } \\
\text { should be } \\
\text { obligatory. } \\
\text { Speculating future } \\
\text { chaos, if 'holes in } \\
\text { the wall' are not } \\
\text { fixed. Changing } \\
\text { the Finnish Aliens } \\
\text { Act. }\end{array}$ & $\begin{array}{l}\text { Asylum seekers } \\
\text { from a 'safe } \\
\text { country' should be } \\
\text { sent back. } \\
\text { Speculating on } \\
\text { organised or } \\
\text { illegal immigra- } \\
\text { tion. }\end{array}$ & $\begin{array}{l}\text { How to prevent } \\
\text { asylum seeking in } \\
\text { a civilised } \\
\text { manner? }\end{array}$ & $\begin{array}{l}\text { Finland's asylum } \\
\text { policy is loose. }\end{array}$ \\
\hline $\begin{array}{l}\text { Problem/cause/ } \\
\text { solution }\end{array}$ & $\begin{array}{l}\text { Problem 1: 'flood } \\
\text { of immigrants' } \\
\text { Problem 2: } \\
\text { administrative } \\
\text { problems }\end{array}$ & $\begin{array}{l}\text { Solution to 'flood' } \\
\text { of immigrants and } \\
\text { to administrative } \\
\text { problems. Solution } \\
\text { to the problem of } \\
\text { loose policy. }\end{array}$ & $\begin{array}{l}\text { Argument backing } \\
\text { up fortress theme } \\
\text { and reputation } \\
\text { theme. }\end{array}$ & $\begin{array}{l}\text { Problem 3: } \\
\text { Finland's } \\
\text { reputation. }\end{array}$ & $\begin{array}{l}\text { Problem } 4 \text { : asylum } \\
\text { policy is too loose. } \\
\text { Causes flood. } \\
\text { Theme used as } \\
\text { solution to } \\
\text { reputation } \\
\text { problems. }\end{array}$ \\
\hline $\begin{array}{l}\text { Catchphrases and } \\
\text { metaphors }\end{array}$ & $\begin{array}{l}\text { 'Flood', 'mass } \\
\text { immigration', } \\
\text { 'flow', 'crowded } \\
\text { refugee centres', } \\
\text { 'invasion'. }\end{array}$ & $\begin{array}{l}\text { 'Quick turn away', } \\
\text { 'faster procedure'. }\end{array}$ & $\begin{array}{l}\text { 'Without } \\
\text { justification.' } \\
\text { 'Organized } \\
\text { immigration.' }\end{array}$ & $\begin{array}{l}\text { No catchphrases. } \\
\text { Talk appears more } \\
\text { indirectly. }\end{array}$ & $\begin{array}{l}\text { 'Easy access.' } \\
\text { 'Attractive asylum } \\
\text { policy.' }\end{array}$ \\
\hline Visual images & $\begin{array}{l}\text { The Roma flowing } \\
\text { towards camera } \\
\text { from customs. } \\
\text { Groups } \\
\text { photographed } \\
\text { rather than } \\
\text { individuals. }\end{array}$ & $\begin{array}{l}\text { A TV news story } \\
\text { ends with a shoot } \\
\text { showing the back } \\
\text { of a departing bus. } \\
\text { Sign 'OUT' } \\
\text { besides a bus full } \\
\text { of Roma. }\end{array}$ & $\begin{array}{l}\text { Not obvious in } \\
\text { visual images. } \\
\text { Visual material } \\
\text { could be read } \\
\text { supporting the } \\
\text { illegitimacy theme } \\
\text { when analyzed in } \\
\text { the context of text. }\end{array}$ & $\begin{array}{l}\text { Not obvious in } \\
\text { visual images. }\end{array}$ & $\begin{array}{l}\text { Images supporting } \\
\text { the flood: there is } \\
\text { nothing to stop } \\
\text { them at the } \\
\text { airport. }\end{array}$ \\
\hline
\end{tabular}


Finnish Roma have been presented through this frame of laziness for decades. This must be one reason why the frame was adopted so spontaneously. The second cause for the 'flood' is seen in the Finnish asylum policy. It is represented as lax by the media text itself as well as by authoritative sources from the Finnish government and ministries as well as by Slovakian authorities.

The fortress theme enters the scene after the first days as a solution to flood problems. The Minister of the Interior sets the agenda with his press release and brings the idea of changing visa regulations and the Finnish Aliens' Act into the public sphere. Though visual metaphors concentrate on 'the flood', some visual and narrative elements also produce the fortress theme. For instance, one television news story which talks about visa requirements and the 'quick turn away' possibility ends with a shot of the back of a departing bus.

Finland's reputation is discussed in only a few stories. It is not a big issue, but the worry of having to be embarrassed is implicit in some stories. For example, the Minister of the Interior mentions in his interview that 'the Roma will be dealt with in a way which will stand international comparison'. Reputation problems seem to be finally solved after the Slovakian Secretary of State has clearly stated to the Finnish press that the Roma are only after 'attractive asylum policy and social welfare'.

Reference to illegitimacy, that is to organized immigration and to having no justification for an asylum application, backs up arguments for building up a fortress and for doing so without image problems. Imposing visa requirements and changing the law so that it cannot be misused seems only natural after the Roma have been given a bad name. Moreover, the flood theme justifies the fortress theme. As an example, both of these themes can be found in the statement the Minister of the Interior gave to the press after the visa requirement for Slovakian citizens had been announced. He justifies the construction of a heavier fortress (visa requirement) with the fear of a future chaos of flood:

It was found that there are no other effective means to be used and one wanted that the situation would not become uncontrollable. (YLE evening news July $\left.6^{\text {th }} 1999.\right)$

\section{Unexpectedness of the 'Flood'}

The first news items emphasize that the Roma's asylum seeking is unexpected and new. Though some authoritative sources from the police, border con- trol, and the Ministry of Labour bring up the novelty in their quotations, it is clear that the media desires this definition. Unexpectedness implicitly refers to an idea that there is no serious human rights violations taking place in Slovakia. Otherwise the authorities and the media would have heard about it before. Therefore emphasis on novelty disparages the Roma's reasons for leaving. Secondly, unexpectedness relieves the pressure of the authorities who might be criticized because they are not capable of dealing with some hundreds of asylum seekers. The fact that some authorities admit that they were taken over could be used as an argument of criticism (since they are not aware of what is happening in Eastern Europe), but this is not done. The media is keen on representing the case as novel and unexpected since these are one of the key criteria for an event to become news. The novelty is emphasized in the beginning of the reporting.

The flood of asylum seekers during the peak summer holiday season means trouble. 'One has not been prepared for this kind of situation.' (Helsingin Sanomat June 29 $9^{\text {th }} 1999$.)

Situation took over both special analyst Veikko Pyykkönen from the Ministry of Labour and the Alavo reception center where more than half of the gypsies have been placed. (Hufvudstadsbladet June 29 $\left.{ }^{\text {th }} 1999.\right)$

Suddenness also implicitly constructs a non-history for the Roma. It seems that the Roma do not have a history before entering Finland. Or, at least they do not have a history that can be relied on. For instance, a morning discussion in television begins like this:

Good morning and welcome. We now talk about asylum seekers, especially the 300 Slovakian Roma, who dropped into Finland during Midsummer. (YLE1, Morning TV, 29.6.)

The Roma just unexpectedly drop in, without any specific reason or difficulty. When the Roma's reasons for leaving are expressed, it is done in a way that leaves it uncertain whether the story is true or not. Discrimination by the police and other Slovakian authorities, discrimination in schooling and skinhead violence are mostly expressed along with a doubt. As an example, the printed media always present the reasons for leaving in direct or indirect quotations which emphasize that according to the Roma, they face discrimination in Slovakia. In comparison, arguments of the Finnish authorities or Slovakian authorities are not framed this way. 
According to their own words they did not leave for a better standard of living. (YLE1 evening news July $\left.4^{\text {th }} 1999.\right)$

\section{Desk Journalism Producing the Frame of Authorities}

The main perspective the media chose is that of the Finnish authorities: problems they face. Another important perspective, the story of the Slovakian Roma, is mostly overlooked. More in some media, less in others. If the Roma's story is dealt with, it is often done through a third person: a Finnish authority or specialist. However, the Roma and the authorities are never presented together: discussing or in the same picture. The Roma's experiences are stressed to be their side of the story, whereas the authorities' angle is presented more neutrally as a fact. For instance, Slovakian Secretary of State Jan Figel 'assured to the Finnish Secretary of State Jukka Valtasaari that Slovakia will take care of the Roma problem before the country's possible EU membership.' (Helsingin Sanomat July 6 $6^{\text {th }} 1999$.) The journalist accepts without a doubt the definition 'the Roma problem'. In the first evening news item about the Roma at YLE 1 the Roma are interviewed. One Roma tells in direct quotations about skinhead violence. However, soon after that episode the journalist frames a Finnish authority's quotation with a line:

There seems to be no answer to why the Roma rush/dash into Finland right now.' And the official continues: 'Usually asylum seekers have some reason, an element of persecution or something which drives them to travel. These, I do not know what is behind this group. (YLE 1, June 29 1999 .)

By framing the official's quotation neutrally ('there seems to be no answer') the journalist undermines the Roma's argument on discrimination and skinhead violence presented earlier in the news item. Moreover, the official uses a derogatory definition 'these (people)'.

It is never openly stated that the Roma are economic refugees. On the contrary, this accusation appears indirectly. For instance, the Swedish language daily paper has headlines like 'Slovakian Secretary of State Jan Figel: Gypsies economic refugees' and 'Slovakian Gypsies: We are not economic refugees'.

There are significant differences in the ways separate media approach the national level of this news topic. The first division in my research material runs between the national, Helsinki centred media, (HS, both $Y L E$ news and $H B L)$ and the regional medium $(K S)$. The former position themselves close to the national viewpoint, whereas the latter positions itself furthest away from the problems the Ministries of Labour and the Interior as well as from the discussion around the Finnish Aliens' Act. Instead, it approaches the topic from a regional point of view. This is not to say that the regional paper does not embrace an elite approach, it does. It does so by using local elite sources, such as city authori-

Table 3. Sources

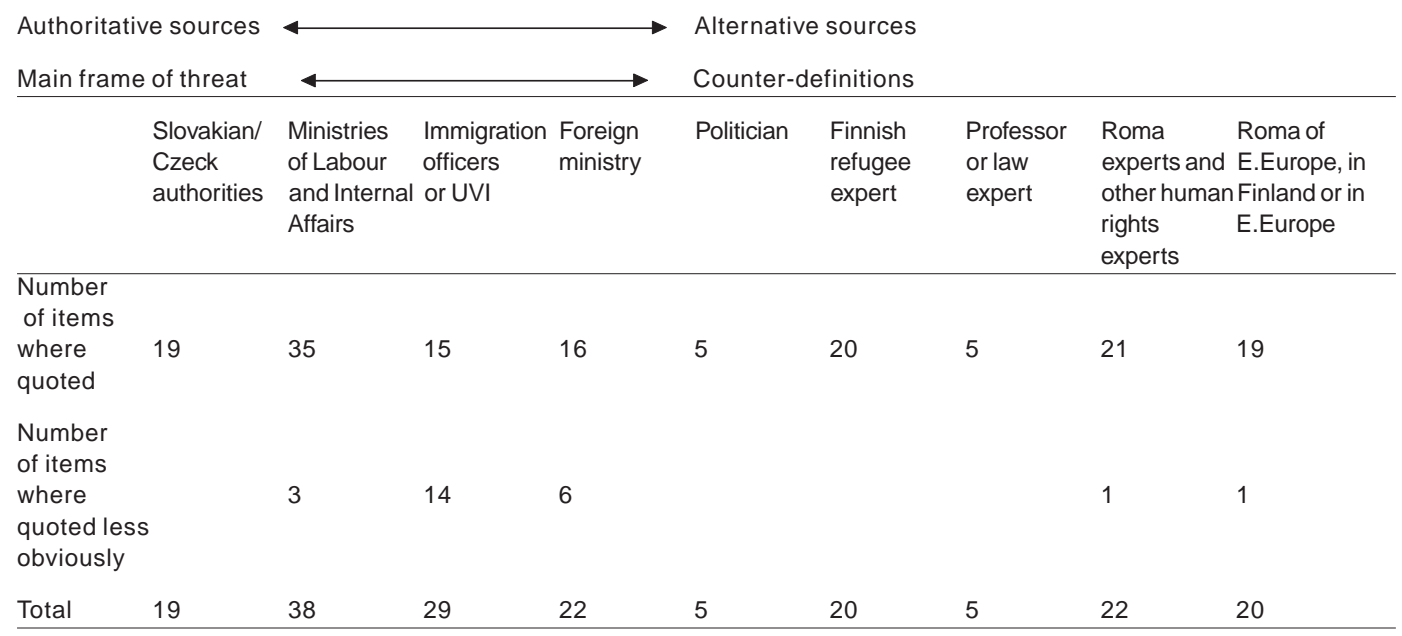

Sources used during the research period. Total amount of items is 126 because small teases on front pages are included. 
ties and local refugee workers. The local view, however, tends to be closer to the viewpoint of the asylum seekers. They are interviewed and photographed more often than in the national media.

The second division appears between the largest daily paper, Helsingin Sanomat, and the rest of the national media. $H S$ clearly operates closest to the national elite. It never interviews the Roma who have arrived in Finland, it never offers eye contact with asylum seekers in its visual images. Instead, it favours the Finnish authorities and sympathizes with the problems they face with immigration.

The largest and only nation wide newspaper, Helsingin Sanomat, tends to practise 'desk journalism" in the reporting on the Slovakian Roma. Its journalists rarely moved from their desks. The journalists produced almost all the material by using telephone and Internet. It is striking that the Helsingin Sanomat did not once interview a Roma who had come to Finland. This is fairly exceptional, though. Other media favour authoritative (mainly Finnish) sources as well, but they do not totally ignore the asylum seekers.

There is only one exception to this argument. The paper sent its journalist and photographer to Slovakia soon after the public awareness was awakened to the Roma issue. The Helsingin Sanomat published an extensive report on its special Sunday pages. There one is able to hear the Roma's voice and look into their eyes. However, it is interesting that this is done in the context of foreign reporting: the journalist was able to face the Roma THERE, in their territory, but not HERE. Moving the topic from the category of internal affairs to foreign affairs gives it a more distant position. Distance gives a different perspective. It is not necessary to link the story to local Finnish political or social circumstances. Bad schooling, housing, and discrimination can be discussed in a less problematic way if it is done far away. Furthermore, the genre of Sunday pages diverts attention from social and political issues. The genre favours more story-telling and a fantasy oriented approach compared to the news genre.

The news at $Y L E$, both Swedish and Finnish, as well as the Swedish language daily paper, Hufvudstadsbladet, do not fall into as tight a marriage with elite authorities as the Helsingin Sanomat. Their sources are also mainly the Ministries of Labour and the Interior, the Directorate of Immigration, the Border Guard, and the refugee organizations, but all of them included the Roma as sources. One motivation for the television news genre to go and meet the Roma is the need for visual material.

\section{Easy Morning Genre}

The media took a supportive attitude towards the Finnish authorities in all genres and in all media. I look more closely into one genre, breakfast television discussion which uses both one-to-one interview and talk show techniques. However, the relationship between the journalist and the guest is always very friendly. The breakfast news programmes in general are relatively light and positive compared to the evening programmes. Television discussion is an excellent corpus of data to analyze how journalists communicate with their sources.

The morning discussions on YLE Channel 1 dealt with the Roma four times during the two week period (June $29^{\text {th }}$, July $2^{\text {nd }}$, July $6^{\text {th }}$, July $7^{\text {th }}$ ). Two interviewees were officials, one a Finnish professor researching the Roma, and one a Finnish Roma specialist (a Roma himself). All interviewees are established sources, they represent some institution. The third discussion was the only one where a critical voice (the Finnish Roma specialist) was presented together with an authority.

The first interview was shown right at the beginning of the news flood. Though the anchor promises in the introduction that 'we will ask why there are refugees coming from Slovakia' the programme fails to present their reasons for leaving. Instead, the interview concentrates on problems the Finnish authorities face with asylum seeking.

The journalist feels empathy towards officials in their difficulties with the 'flood of immigrants'. Equally, the official in his discourse approaches the journalist. He speaks in a less formal manner. They both continue each others' thoughts and sentences.

Journalist: Have there been asylum seekers from Slovakia before?

Official: In May it began to be clear that Slovakians started to move. In April, 30 people came from the area of Slovakia.

Journalist: and then evidently the word went around in the homeland.

Official: It looks as if the word has gone around. It has been foreseen that more groups are coming.

Journalist: It seems as if there is a new kind of hustle bustle for us Finns.

(YLE 1 breakfast show, June 29 $\left.{ }^{\text {th }} 1999.\right)$

The discursive dance together goes so smoothly that the audience is invited to participate as well. The journalist invites 'us Finns' to feel empathy for the hustle bustle that the authorities are going through. 
Finally, the authorities, the journalist, and the audience become one, 'us Finns'. From this kind of position, it is totally impossible for the journalist to take a critical view towards the authorities. Moreover, the possibility for a critical position is removed from the audience as well by the discursive invitation 'us Finns'.

\section{Oneway Communication: Alternative Discourses React to Elite Discourses}

There is a significant lack of counter definition to the main frame of threat and the themes of flood, fortress, lax policy, and illegality. The few alternative views presented are just reactions to the main frame set by the authorities. Therefore, they do not bring any new themes into the public sphere, instead they continue along the same themes. Another important feature is consensus among the Finnish authorities. This case did not raise any political discussion. On the contrary, most politicians were silent. During the two week period only one politician, the Minister of Interior, actively presented his views in the media. He spoke for visa requirement and tightening the Aliens Act. Opposite political views were not presented in the Finnish language media.

However, there is some variation among the media I analyzed. The main division among the national media runs along the language line: the Swedish language media tend to be more critical towards authorities than the Finnish language media. They present authorities' fortress talk in a more problematic way. For instance, when most Finnish media praise the government's visa requirement in their editorials, the Hufvudstadsbladet questions the decision in its editorial:

Visa decision awakens questions (HBL July $7^{\text {th }} 1999$ ).

Both the Swedish language television news and the newspaper use more alternative voices than the Finnish ones. Critical views are most frequently presented by a Finnish Roma specialist (a Finnish Roma himself), but also two politicians, a head of a refugee organization, and an Amnesty International worker appear questioning the government's decisions. Though elite sources do not respond to their views, critical arguments are often presented in the same story with the authorities. The Finnish language media use much fewer alternative voices and present them separately from the elite discourse.

This is an important difference since mixed message appears to some extent in all media. On the one hand there is a strong support for the fortress theme of the authorities, on the other hand counter arguments or doubts appear, such as criticism towards accepting Slovakia as 'safe'. How these counter arguments are framed and presented in the media, however, is crucial. Firstly, critical views or questions are often effectively nullified by the authority of official sources. Secondly, counter arguments are presented separately from the main news item which is based on elite sources. For instance, Helsingin Sanomat gives a summary of an interview with an expert from Slovakian Legal Defence Bureau of Ethnic Minorities about the discrimination in Slovakia. This item is published in the same page with a story based on the meeting with Slovakian and Finnish Secretaries of State. This main news story clearly emphasises illegality theme and fortress theme. The headline hopes for visa regulations:

Compulsory visa was not yet posed on Slovakians

And the journalist has adopted the phrase 'Roma problem" without a doubt into her text. The two contradictory definitions of the situation in Slovakia, the 'Roma problem' set by the Secretary of State and the 'human rights violations' set by the Slovakian minority organization, are presented separately without discussion. It is clear that the frame set by the Slovakian Secretary of State stands out more convincing. It gets more column space, a photo, and Slovakian authority's arguments against the Roma are backed up by a Finnish Secretary of State.

There are differences in the use of language as well. One interesting notion is that when the Finnish television news announces that 'Finland stops the Roma refugee flow with a visa requirement', the Swedish news reports in a more exact manner that 'the government stops the arrival of the Roma with a visa requirement'. The use of language makes a difference since "Finland" invites the audience to believe that they are behind the decision as well. On the contrary, there is no need to feel as strong solidarity towards 'the government'. Furthermore, the Swedish language anchor continues to remind the audience that 'the decision comes in for serious critique', whereas the Finnish language news story does not offer any counter definitions.

Another difference is that the Swedish language media do not repeat fortress theme as intensively. Instead, Nytt and Hufvudstadsbladet give more column space to the Roma perspective. Television news has more visual material from Slovakia and more discussion about the reasons for leaving Slovakia. 
There is a difference in the footage between the Swedish language television news and the Finnish one. The Swedish language news uses footage from a poor Roma ghetto in Slovakia in three news casts out of eight (material from the archive) where as the Finnish news uses this type of material only once out of ten news casts (correspondent's story from Slovakia). The context where the Finnish news uses images of a poor neighbourhood, dirty children, rubbish on the streets, open gutters, and run down block houses, is such that these images support the illegality theme. Images testify that the Roma left for the money. The Swedish language news on the contrary cuts these images between interviews and journalist's talk where discrimination is discussed. Therefore, the images support and testify an alternative framework: the Roma are discriminated.

\section{European Trend: Asylum Seekers as Security Threat}

The case of the Roma illustrates how both global hierarchies and national immigration policy are negotiated in the public sphere. The media play a central role in the process of defining who are good immigrants and who are not. Moreover, the media supported the idea of changing the Aliens' Act.

The media chose to frame the event mainly with the themes of flood, illegitimacy, lax policy, and fortress building. Furthermore, they chose to present the official perspective as the most reliable and important. Choosing desk journalism supported the authorities. These were all decisions which left something else untold. The talk and images of invasion, illegitimacy, and uncontrolled flood frequently associated with asylum seeking paints a picture that asylum seekers are a dirty chaos which should be kept out. They are presented as a security threat to Finnish law and order. These Roma families with small children, however, could be seen in another light as well. Finland will be experiencing a lack of labour force in most sectors of the economy in the near future. Asylum seekers could be seen as active and having the courage to pursue a better life. The aspect of labour was totally omitted from the themes relating to the Roma.

The Roma's mobility was presented as illegitimate and it was implicitly suggested that they should accept their destiny and stay in their locality. The media presented fortress as the main solution to "the flood". Though the Swedish language media and its alternative (though established elite) sources were slightly questioning the government's decisions they did not offer the possibility of an asylum or residence permit as an option. Their solution was that Finland should actively work for a better human rights situation in Slovakia. Finland was presented as responsible for (global) problems, such as the marginalization of the Eastern European Roma, but the Roma's right for mobility was not supported.

The media as well as its major sources, the authorities, are unable to see asylum seekers as rational people. Leaving the Roma story mainly unheard, the media took away the possibility of understanding the 'Other'. Journalism is making choices and these choices construct certain frames. Journalism tends to stick to frames rather than to invent alternatives. Presenting asylum seekers as a threat rather than a resource, as dirt and chaos rather than people making rational decisions, the media reproduces global hierarchy where certain groups, like the Roma, are stuck in the lower strata.

The reputation theme was not a big issue in the media, which is no surprise. Immigration laws have been tightened in all European countries as well as in European Union policy. The key idea in the Schengen agreement is to construct a wall around EU and drop control between the countries. Finland by killing hopes of the Roma was only following the trend, being a good EU country. If it had done something exceptional, like giving asylum to some of the Roma, it would have had image problems. In Appadurai's $(1996,6)$ terms, the Roma were not considered to manifest a sufficient diaspora of terror or despair. Nor were they considered suitable people for the diaspora of hope.

Bauman $(1998,88)$ argues that there is less and less communication between the top and the bottom of global hierarchy. This seems to be the tendency if we look at the case of the Slovakian Roma. Elite sources, officials from the Ministries of Labour and the Interior, officials from the Directorate of Immigration and the heads of refugee centres, are the ones who negotiate what should be done with the Roma and set the agenda. The media mainly keep alternative voices separate from elite discourses. Therefore, there is no negotiation between critical views and elite views.

Furthermore, the Finnish authorities as well as the Finnish media favour the Slovakian authorities, the Secretary of State and the Foreign Minister to the Roma themselves. Jan Figel, the Secretary of State, appears as one of 'us'. He speaks the same language (English, formal discourse) and dresses in a white collared shirt and a suit. Both the authorities and the media prefer communication with him to the Roma. This example demonstrates how in some respects the people of the world are not as much di- 
vided by national borders as they are divided by economic and social status, class.

One explanation for the negative attitude towards the Roma from Slovakia is definitely the problem Finnish society has in facing their ethnicity. Finland has had a small Roma minority for more than 500 years. They still experience discrimination and marginalization in Finnish society. The majority knows very little about them, and the general attitude is negative (Jaakkola 1999, 147) ${ }^{3}$. If the newcomers from Slovakia would have been, shall we say, from the Hungarian minority of Slovakia, attitudes may have been more positive. The fact that they were Roma, and that their ethnicity was emphasized in the media, was certainly a building brick for negative representation. According to racist argumentation, ethnicity is understood to determine peoples' behaviour and to be non-transferable. Racist logic classifies people into unified groups according to some charasteristics, like skin colour or dress. Emphasis on difference and partly imagined characteristics defines the group as unified. The group turns into the prisoner of imagined characteristics. Future and changes do not apply to its members. Racist argument in this case would claim that the Roma are the same everywhere. (Guillaumin 1993; Castoriadis 1987, 25.)

In addition to the negotiation of global hierarchy this case demonstrates how the media played a central role in national immigration policy. Changing the Finnish Aliens' Act fast was not on the govern- ment agenda before the Roma came. Firstly, repetition of the illegitimacy and flood themes did the groundwork for the fortress theme to emerge. Characterising the "flow of the Roma" as new and unexpected supported ideas of flood and economic refuge. When the Roma had been given a bad name and it was repeatedly reported that there was an endless flow of them coming, the public climate was ready to tighten the Aliens' Act. The lack of political discussion and lack of strong counter force against the fortress project is nothing very new in the Finnish culture. Studies on ethnic minorities and the media repeatedly bring up the issue of silence: politicians prefer not to touch the issue of asylum seeking (Horsti 2002). Silent consensus for the fortress theme in the case of Eastern European Roma seems to run through the whole society.

Secondly, the media repeated over and over again that the only way to stop the flow would be imposing a visa requirement and tightening the Aliens' Act. These options became neutral facts without any alternatives. The Minister of the Interior, Kari Häkämies, was the one who brought the fortress theme into the media agenda. He repeatedly demanded that the Aliens' Act be changed so that 'a quick turn away' would be possible. His proposal was accepted by the government and the parliament with some changes. An interesting detail is that a year after the Roma were denied access a tabloid paper announced him to be the most popular conservative politician in the country.

\section{Notes}

1. Teasers on front pages have not been counted separately.

2. 1st phase - news 12 items, features and commentaries 4 items. 2 nd phase -14 items: 9 items. 3 rd phase 32 items: 25 items. 4 th phase -8 items: 6 items.

3. 25 per cent of the majority of Finns would have a positive attitude towards marring or experiencing a close friend or relative marring a traditional Roma In comparison, 74 per cent would have similar positive attitude towards the traditional Sami minority.

\section{References}

Anderson, Benedict (1983) Imagined Communities. Reflections on the Origin and Spread of Nationalism. London: Verso.

Appadurai, Arjun (1996) Modernity at Large. Cultural dimensions of Globalization. Minneapolis: University of Minnesota Press.
Bauman, Zygmunt (1998) Globalization. The Human Consequences. Cambridge: Polity Press.

Blomqvist, Outi (1996) 'Mustien on määrä viipyä Valkealassa enintään kuukauden. Pakolaiset suomalaisissa sanomalehdissä.' In Jyrki Kalliokoski (ed.): Teksti ja ideologia. Kieli ja valta julkisessa kielenkäytössä. Helsinki: Helsingin yliopiston suomen kielen laitos, 131-150.

Brosius, Hans-Bernd \& Eps, Peter (1995) 'Prototyping through Key Events. News Selection in the Case of Violence against Aliens and Asylum Seekers in Germany', European Journal of Communication 10(3): 391-412.

Cahn, Claude and Trehan, Nidhi (1997) Time of the Skinheads. European Roma Rights Center Reports.

Castoriadis, Cornelius (1997) Magma. Tutkielmia yhteiskunnan imaginaarisista instituutioista. Juva: Hanki ja jää.

Entman, Robert M. (1991) 'Framing U.S. Coverage of International News: Contrasts in Narratives of the KAL and Iran Air Incidents', Journal of Communication 41(4): 6-27. 
Entman, Robert M. (1993) 'Framing: Toward Clarification of a Fractured Paradigm', Journal of Communication 43(4): 51-8.

Fairclough, Norman (1995) Media Discourse. London: Edward Arnold.

Finnäs, Fjalar (1997) 'Suomen ruotsinkielinen vähemmistö’ pp. 48-83. In Juha Pentikäinen \& Marja Hiltunen (eds) Suomen kulttuurivähemmistöt. Helsinki: Suomen Unesco-toimikunnan julkaisuja No 72.

Gamson, William A. \& Modigliani, Andre (1989) 'Media Discourse and Public Opinion on Nuclear Power: A Constructionist Approach', American Journal of Sociology 95 (1): 1-37.

Goffman, Erving (1974) 'Frame Analysis. An Essay on the Organization of Experience'. York, Pennsylvania: The Maple Press.

Grönfors, Martti (1997) 'Suomen romanivähemmistö: unohdettu kulttuuriryhmä', pp. 149-160. In Juha Pentikäinen and Marja Hiltunen (eds) Suomen kulttuurivähemmistöt. Helsinki: Suomen Unesco-toimikunnan julkaisuja No 72 .

Guillaumin, Colette (1993) 'La "différence culturelle", pp. 149-151, In Michel Wieviorka (ed) Racisme et modernité. Paris: Éditions la découverte.

Hall, Stuart et al (1978) Policing the Crisis. Mugging, the State, and Law and Order. London: Macmillan Education.

Hirchman, Albert O. (1970) Exit, Voice, and Loyalty: Responses to Decline in Firms, Organizations, and States. Cambridge: Harvard University Press.
Horsti, Karina (2002) 'Marginalizing ethnic minorities in the Finnish media'. In Jessika ter Wal (ed.) Racism and Cultural Diversity in the media. Vienna: EUMC.

Jaakkola, Magdalena (1999) Maahanmuutto ja etniset asenteet. Suomalaisten suhtautuminen maahanmuиttajiin 1987-1999. Helsinki: Edita. Työpoliittinen tutkimus 213.

Kantola, Anu (2001) 'Leaving Public Life. The Anti-politics of the Finnish Public Sphere in Transnational Times'. Paper presented at the Transnational Public Sphere Conference at the University of Tampere, Finland. 12-14 January 2001.

Liebkind, Karmela (1997) 'Suomen ruotsinkielinen vähemmistö' pp. 48-83. In Juha Pentikäinen \& Marja Hiltunen (eds.) Suomen kulttuurivähemmistöt. Helsinki: Suomen Unesco-toimikunnan julkaisuja No 72.

Pietikäinen, Sari (2000) Discourses of Differentations. Ethnic Representations in Newspaper Texts. Jyväskylä studies in communication 12. Jyväskylä: University of Jyväskylä.

Raittila, Pentti (2002) Etniset aiheet, vähemmistöt ja niiden suhteet suomalaisessa journalismissa vuonna 2000. In Raittila (ed) Etnisyys ja rasismi journalismissa. Tampere: Tampere University Press.

Wall, Melissa A. (1997) 'The Rwanda Crisis. An Analysis of News Magazine Coverage'. Gazette 59 (2): 199134. 